\title{
Informal Cross-Border Trade in Africa
}

\author{
Kathryn Pace, Antoine Bouët, and Joseph Glauber
}

Access to high-quality data is a key component for research and subsequent policy recommendations; however, accurate trade data capturing intra-African trade is not consistently available to researchers, even in commonly used databases such as UN COMTRADE. Formally reported country-level trade data can be reported at erratic intervals, is frequently inaccurate, and generally does not account for informal trade. Several studies (Ama, Mangadi, and Ama 2014; Ogalo 2010; INSAE 2011 and 2012; Bensassi et al. 2016a and b) suggest that informal cross-border trade (ICBT) can meet or even exceed the value of formal trade in certain trade corridors. This shows how important ICBT is to economies, and how important it is to get an accurate measurement.

Informal trade is a key source of income for many poor rural African households. According to Afrika and Ajumbo (2012), ICBT provides a source of income for approximately 43 percent of Africa's population. Informal trade also plays an important role in terms of food security: in West Africa, a food-deficit region, ICBT in staple foods accounts for about 30 percent of total trade in the region (USAID 2015).

As noted in Bouët, Pace, and Glauber (2018), informal trade plays a significant role for women as it is known that many actors in the informal labor and informal trading economies are female. In the Southern African Development Community (SADC) region, female traders account for approximately 70 percent of informal cross-border traders (United Nations Development Fund for Women 2009). In Western and Central Africa, women account for nearly 60 percent of informal traders (Afrika and Ajumbo 2012). The Organisation for Economic Co-operation and Development (OECD) states that for women "informal trade often constitutes the sole source of earnings and economic empowerment" (Lesser and MoiséLeeman 2009, 16). ICBT has the potential to create jobs in rural areas, particularly for women who may not have the time or support necessary to enter formal employment channels (UNCTAD 2018; Mbo'oTchouawou et al. 2016).

As ICBT appears to be so large and is heavily linked to food security, economic development, and women's empowerment, it is important to obtain accurate measurements of this type of trade. More accurate data can improve the statistical measurements of balance of payments and external accounts, improving global trade measurement and modeling, and facilitate the development of more accurate domestic food balance sheets. Overall, measurement of ICBT in Africa can provide a more accurate picture of other aspects related to informal trade, including information on informal labor markets and 
movement patterns of staple foods during periods of crises. Each of these provides the opportunity for better policymaking using reliable and accurate data.

\section{Types of ICBT}

There are several types of ICBT that can occur, namely: (1) informal, unregistered traders that operate entirely outside of the formal economy; (2) formal, registered traders that completely evade regulations and duties by any means including avoiding official crossing points (full evasion); and (3) formal, registered traders resorting to practices such as under-invoicing or declassifying (partial evasion) (Lesser and Moisé-Leeman 2009, 10). We reserve definition (2), full evasion, to describe smuggling.

Lesser and Moisé-Leeman (2009) find that small businesses that are not formally registered tend to also trade informally. The existence of a permanent informal sector is related to limited access to finance, limited market information, and limited knowledge, education, and business management skills. Due to the extensive and fluid nature of the informal economy, this type of trading may have a positive effect in the short term in terms of food security and income of poor households, particularly in times of crisis. However, in the long term there may be negative consequences, including lack of food safety, less investment in the formal economy, and a decrease in public revenues leading to less investment in infrastructure and public services.

\section{Measurement of ICBT}

There are currently several methods being used to measure ICBT, including field surveys focused on informal traders (definition (1) above), econometrically estimating mirror trade flows by looking at discrepancies between a country's reported imports and its trading partners' reported exports, and attempts at measuring smuggling done by formal traders (definition (2) above), particularly in West Africa. In general, the attempts to measure ICBT have been poorly coordinated across the continent and the data resulting from many of the surveys remain privately held. An overview of studies measuring ICBT across Africa, available from Bouët, Pace, and Glauber (2018), covers key information including the method, location, implementors and funders, and years and products covered in each study.

The majority of field surveys conducted recently have been targeted to specific regions or trade corridors in Africa and cover a limited time frame. Two notable surveys in Uganda and Rwanda have been ongoing for longer periods of time, since 2005 and 2009 respectively, and are supported by their national governments which use these data in official reports. A third ongoing survey covering the West Africa region, led by the Permanent Interstate Committee for Drought Control in the Sahel (CILSS), is also a notable ongoing program with work underway to integrate this data into official Economic Community of West African States (ECOWAS) statistics, but in this program data is collected on all formal and informal trade, not on informal trade alone.

\footnotetext{
The Uganda program, as mentioned, started in 2005 and is financed by the Uganda Bureau of Statistics (UBOS) and the Bank of Uganda (BoU). The program primarily measures ICBT definition (1), capturing information from informal traders on Uganda's borders with the Democratic Republic of Congo (DRC), Kenya, Rwanda, South Sudan, and Tanzania. As shown in Error! Reference source not found.Source: UBOS and BoU (2007, 2008, 2009, 2010, 2013, and 2014) and authors' calculation.

Note: ICBT = informal cross-border trade.

, while Uganda tends to be a net importer, the share of its informal exports in total exports is significantly higher than informal imports' share of total imports. Informal exports primarily go to the DRC and South Sudan. A large spike in the share of informal exports occurred in 2008 and 2009 during the global food crisis, showing evidence of increased informal movement during crises, which supports Lesser and Moisé-Leeman (2009).
} 
Figure 1: Total and informal exports from Uganda - 2005-2015 - US\$ millions and percent

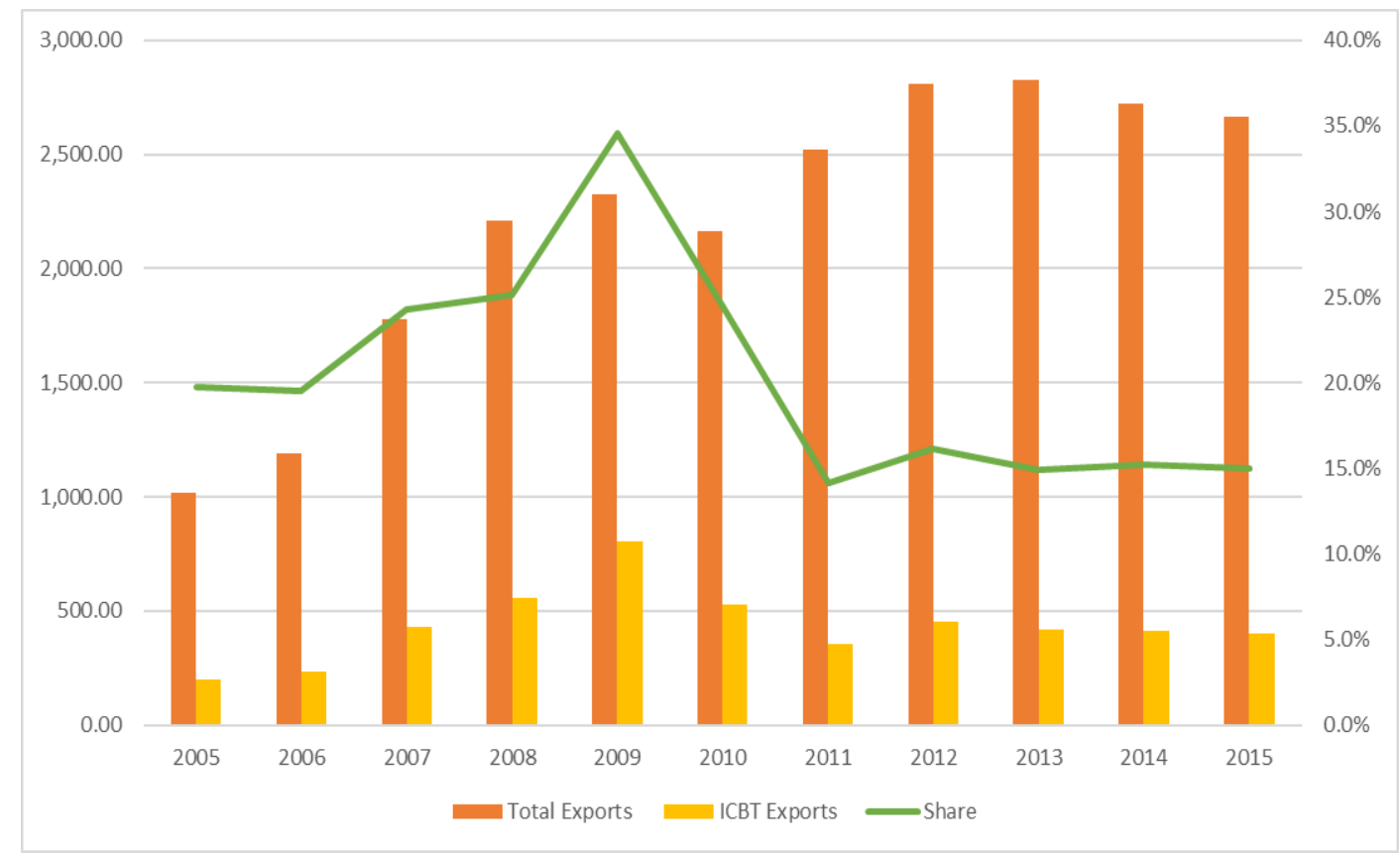

Source: UBOS and BoU (2007, 2008, 2009, 2010, 2013, and 2014) and authors' calculation. Note: ICBT = informal cross-border trade.

Figure 2: Total and informal imports of Uganda - 2005-2014 - US\$ millions and percent

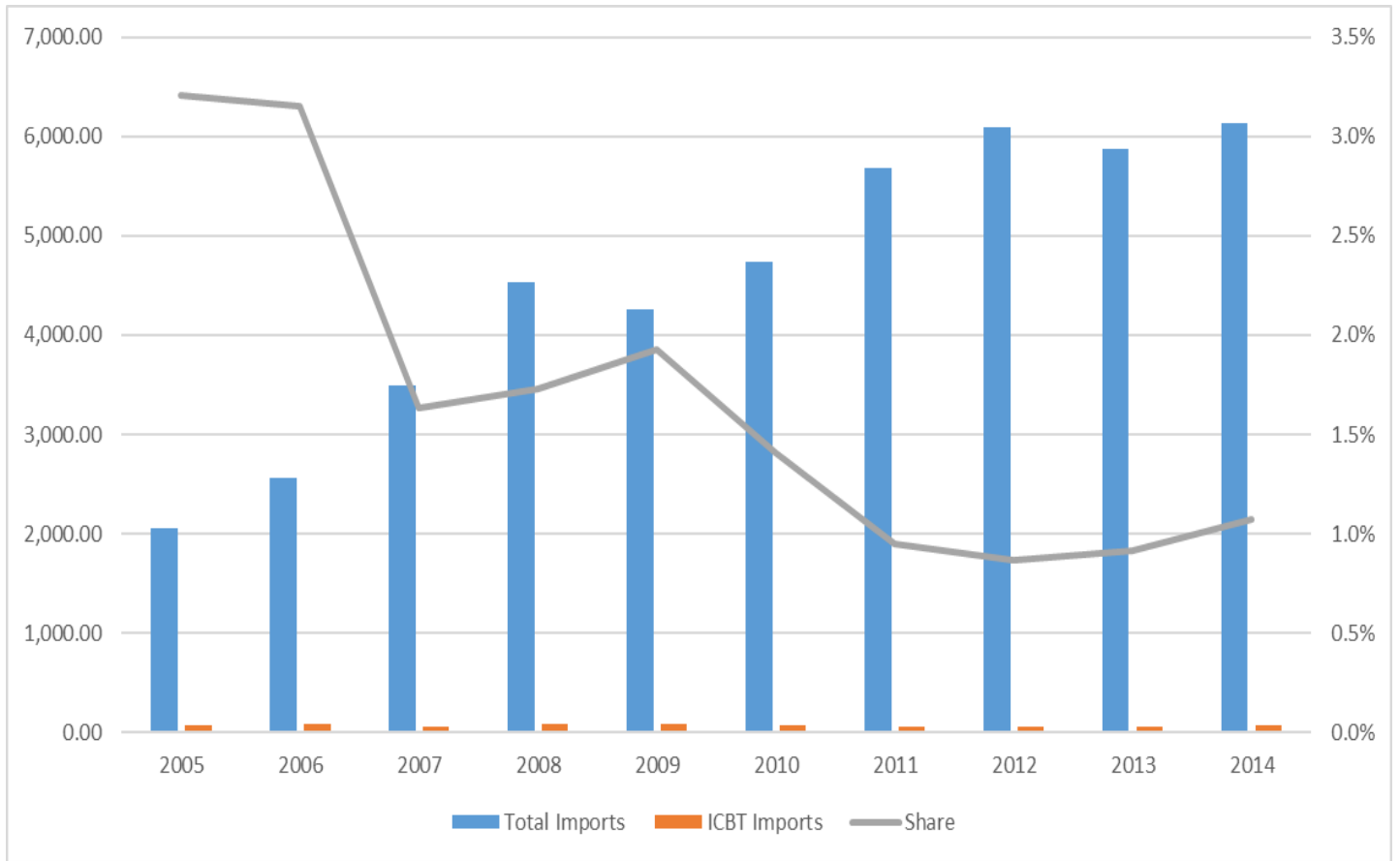


Source: UBOS and BoU $(2007,2008,2009,2010,2013$, and 2014) authors' calculation.

Note: ICBT = informal cross-border trade.

A recent attempt to measure smuggling in West Africa, a survey on informal cross border trade called the Enquête sur le commerce extérieur non enregistré (ECENE), was led by Institut National de la Statistique et de l'Analyse Economique (INSAE) in Benin over a two-week period in September 2011. All posts covered in this survey were illegal border crossing points with Togo and Nigeria. The survey was analyzed by Bensassi, Jarreau, and Mitaritonna (2016a and b), who found that high tariffs and import bans in the region were significant predictors of increased smuggling, as was time sensitivity in terms of perishability of goods that frequently get stalled in legal customs procedures.

A final example of measurement is the program run by CILSS throughout West Africa. They collect information on informally and formally traded goods and are currently working on expanding from 10 transport corridors to 20. CILSS also collects information from truckers while en route from market to market about any bribes or time delays they faced at security checkpoints. The CILSS data are in the process of analysis, with assistance from IFPRI, and incorporation into official ECOWAS databases.

\section{Recommendations on ICBT}

Overall, ICBT is a very large phenomenon in Africa. ICBT appears to be so large, even exceeding formal trade in certain cases, that improved measurement is key for creating an accurate picture of trade and the potential for economic development within Africa. This is particularly important as the continent is entering into the African Continental Free Trade Agreement (AfCFTA) and costs associated with formal trade within the continent are lowered.

ICBT can occur organically, connecting informal markets, but also can also be used purposefully to evade formal regulations in large-scale smuggling. We see increased ICBT as a result of both the extensive informal sector, as well as high monetary and time costs associated with formal trade (Lesser and Moisé-Leeman 2009; Afrika and Ajumbo 2012; Bensassi, Jarreau, and Mitaritonna 2016; Bouët, Cosnard, and Laborde 2017).

There is, however, still limited literature on the implications of ICBT. In the short term, studies generally see positive effects (Meagher 2003; Little 2005; and Lesser and Moisé-Leeman 2009) where ICBT is a large source of income, employment opportunities, and food security for rural households, particularly women. However, in the long term there can be negative consequences, including a loss of national income, and resulting poorer infrastructure and public services. There is also the ongoing issue of a lack of food safety regulation in informally traded goods leading to the potential spread of pests and disease.

Based on the review of ICBT in Bouët, Pace, and Glauber (2018), it is recommended that governments work to encourage movement from informal to formal trade by giving those in the informal sector an incentive to join the formal sector. They may do so by reducing the entry costs to the formal sector, both in terms of time and money, without increasing the cost of informal trade. This can be implemented, for example, by reducing regulatory barriers that occur in the form of extensive certification procedures and licenses, improving infrastructure, and improving capacity building programs for traders to encourage them to move to the formal sector. It is possible that with the new AfCFTA, which will reduce monetary barriers associated with formal trade, we may see a switch from informal trade to formal trade, but ICBT must be accurately measured to see this change. 


\section{ABOUT THE AUTHORS}

Kathryn Pace is a Program Manager with IFPRI's Markets, Trade, and Institutions Division (MTID), and Antoine Bouët and Joseph Glauber are Senior Research Fellows with MTID.

\section{ACKNOWLEDGMENTS}

The research was supported by the United States Agency for International Development (USAID).

\section{REFERENCES}

Afrika, J.-G. K., and Ajumbo, G. 2012. Informal cross-border trade in Africa: Implications and policy recommendations. AfDB Africa Economic Brief, 3(10): 1-13.

Ama, N.O., Mangadi, K.T., and Ama, H. 2014. Characterization of informal cross-border traders across selected Botswana borders. International Journal of Management and Marketing Research, 7(1): 85-101.

Bensassi, S., Jarreau, J., and Mitaritonna, C. 2016a. Determinants of cross-border informal trade: The case of Benin. AGRODEP Working Paper 34. Washington, DC: IFPRI.

Bensassi, S., Jarreau, J., and Mitaritonna, C. 2016b. Informal trade in Benin, Togo, and Nigeria: Determinants and impacts on price transmission. AGRODEP Technical Report. Washington, DC: IFPRI.

Bouët, A., Cosnard, L., and Laborde, D. 2017. Measuring trade integration in Africa. Journal of Economic Integration, 32(4): 937-977.

Bouët, A., Pace, K., and Glauber, J.W. 2018. Informal cross-border trade in Africa: How much? Why? And what impact? IFPRI Discussion Paper 1783. Washington, DC: IFPRI.

INSAE (Institut National de la Statistique et de l'Analyse Economique). 2011. Enquête sur le commerce non enregistré au cordon Douanier. Technical Report. Cotonou.

INSAE. 2012. Enquête sur le commerce extérieur non enregistré au cordon Douanier. Technical

Report. Cotonou.

Lesser, C., and Moisé-Leeman, E. 2009. Informal cross-border trade and trade facilitation reform in Sub-Saharan Africa. Trade Policy Working Papers No. 86. Paris: Organisation for Economic Co-operation and Development.

Little, P. D. 2005. Unofficial trade when states are weak: The case of cross-border commerce in the Horn of Africa. Research Paper No. 2005/13. Helsinki: United Nations University/WIDER (World Institute for Development Economics Research).

Meagher, K. 2003. A back door to globalisation? Structural adjustment, globalisation \& transborder trade in West Africa. Review of African Political Economy, 30(95): 57-75.

Mbo'o-Tchouawou, M., Karugia, J., Mulei, L., and Nyota, H. 2016. Assessing the participation of men and women in cross-border trade in agriculture: Evidence from selected East African countries. ReSAKSS Working Paper No. 38. Washington, DC: IFPRI. Available at

Ogalo, V. 2010. ICBT in EAC: Implications for regional integration and development. Nairobi: Consumer Unity \& Trust Society (CUTS) African Resource Centre.

UBOS (Uganda Bureau of Statistics) and BoU (Bank of Uganda). 2007. The informal cross-border trade survey report 2007. Kampala. UBOS and BoU. 2008. The informal cross-border trade survey report 2008. Kampala.

UBOS and BoU. 2009. The informal cross-border trade survey report 2009. Kampala.

UBOS and BoU. 2010. The informal cross-border trade survey report 2010. Kampala.

UBOS and BoU. 2013. The informal cross-border trade survey report 2013. Kampala.

UBOS and BoU. 2014. The informal cross-border trade survey report 2014. Kampala.

United Nations Conference on Trade and Development. 2018. Informal cross-border trade for empowerment of women, economic development and regional integration in Eastern and Southern Africa. Accessed December 13, 2018. https://unctad.org/en/Pages/DITC/Gender-and-Trade/Gender-Project-1617J.aspx.

United Nations Development Fund for Women. 2009. Findings of the baseline studies on women in informal cross-border trade in Africa. Brussels, Belgium.

USAID. 2015. ACTE Performance Management Plan: Harmonized methodology for data collection of priority indicators. Prepared for USAID (United States Agency for International Development), Washington, DC. 
Funding for this work was provided by USAID. This publication has been prepared as an output of Tracking and Promoting Agricultural Trade Performance by African Countries and has not been independently peer reviewed. Any opinions expressed here belong to the author(s) and are not necessarily representative of or endorsed by IFPRI.

\section{INTERNATIONAL FOOD POLICY RESEARCH INSTITUTE \\ A world free of hunger and malnutrition}

1201 Eye Street, NW, Washington, DC 20005 USA | T. +1-202-862-5600 | F. +1-202-862-5606 | Email: ifpri@cgiar.org | www.ifpri.org | www.ifpri.info 